\title{
Fruit production and quality of sweet orange genotypes selected for the state of Acre, Brazil
}

\author{
Rychaellen Silva de Brito $^{1 *} \odot$, Reginaldo Almeida Andrade ${ }^{2} \odot$, Romeu de Carvalho Andrade Neto ${ }^{3}$ \\ ${ }^{1}$ Universidade Federal do Acre, Rio Branco, AC, Brasil. E-mail: rychaellenbrito@gmail.com \\ 2 Universidade Federal de Rondônia, Rolim Moura, RO, Brasil. E-mail: reginaldo.andrade@unir.br \\ ${ }^{3}$ Empresa Brasileira de Pesquisa Agropecuária, Rio Branco, AC, E-mail: romeu.andrade@embrapa.br
}

ABSTRACT: The Acre State, Brazil, has edaphoclimatic conditions suitable for the cultivation of sweet orange trees; however, production is limited by the lack of genotypes adapted to the region. The aim of this study was to evaluate the production and quality of sweet orange fruits grafted onto 'Rangpur' lime, in order to identify promising genotypes that could be used as a cultivar. The experiment was carried out between 2010 and 2012 in the experimental field of Embrapa, AC, Brazil, in a randomized block design, with 19 genotypes and local Aquiri cultivar. These were propagated by budding, originated from matrices propagated by seeds, and were selected from nine municipalities of Acre, Brazil. A total of 20 treatments with three replications were used in this study. The number of fruits per plant, production per plant, productivity, and fruit quality (fruit mass, longitudinal and transversal fruit diameter, peel thickness, juice yield, soluble solids, titratable acidity, quotient between soluble solids and titratable (ratio), and technological index) were evaluated. Joint analysis of variance and Scott-Knott tests were performed to compare means, as well as Pearson's correlation and cluster tests, using the Ward method and Mahalanobis distance. The sweet orange genotypes $6,8,9,52$, and Aquiri cultivar presented the best productivity indicators, with average values above the national productivity. The isolated effect of the year factor showed a greater number of fruits, production per plant, and productivity in the 2010 harvest.

\section{Produção e qualidade de frutos de genótipos de laranjeiras-doce selecionados}

\section{para o estado do Acre}

RESUMO: O estado do Acre apresenta condições edafoclimáticas adequadas para o cultivo de laranjeiras-doce, entretanto, a falta de genótipos adaptados à região limita a produção. Objetivou-se avaliar a produção e a qualidade de frutos de laranjeirasdoce enxertadas sobre limoeiro 'Cravo', visando identificar genótipos promissores que possam ser lançados como cultivar. 0 experimento foi realizado entre os anos de 2010 e 2012 no campo experimental da Embrapa, AC, Brasil, em delineamento em blocos casualizados, com 19 genótipos, mais a cultivar Aquiri, propagados por enxertia, originários de matrizes seminíferas, selecionadas em 9 municípios do Acre, totalizando 20 tratamentos com três repetições. Foram avaliados o número de frutos por planta, produção por planta, produtividade e os aspectos qualitativos, massa média, comprimento e diâmetro médio dos frutos, espessura da casca, rendimento do suco, sólidos solúveis totais, acidez total titulável, ratio e índice tecnológico. Foi realizada análise de variância conjunta e teste de Scott-Knott para a comparação das médias bem como a correlação de Pearson e teste de agrupamento pelo método de Ward. Os genótipos de laranja-doce 6, 8, 9, $52 \mathrm{e} \mathrm{cv}$. Aquiri foram aquelas que apresentaram os melhores indicadores produtivos, com valores médios acima da produtividade nacional. $O$ efeito isolado dos anos demonstrou maior número de frutos, produção por planta e produtividade na safra de 2010.

Palavras-chave: Citrus sinensis; características fenotípicas; Amazônia Ocidental

\footnotetext{
* Rychaellen Silva de Brito - E-mail: rychaellenbrito@gmail.com (Corresponding author)

Associate Editor: Sérgio Ruffo Roberto
} 


\section{Introduction}

Citriculture is one of the most important agricultural activities for fruit growth (Panta \& Santos Sobrinho, 2019); sweet orange (Citrus sinensis (L.) Osbeck) is the main species of the Citrus genus and is the most produced fruit in the world (Coelho et al., 2019). According to FAO estimates for 2019 (2020), the American continent is responsible for approximately $40.4 \%$ of global orange production; Brazil being the largest producer and exporter, with approximately 17.03 million tons produced annually.

Sweet orange crops are cultivated in all Brazilian regions but the states of São Paulo, Minas Gerais, and Paraná are the main producers, producing 14.9, 0.99 and 0.80 million tons, respectively, anually (IBGE, 2020). Sweet orange is the second most cultivated fruit species in the state of Acre, Brazil, only behind bananas (IBGE, 2020); however, this production does not meet local demand, making it necessary to import fruits from other producing states.

Despite the fact that the Acre State has edaphoclimatic conditions favorable to the expansion of citriculture, there is a lack of information on the adaptation and productive performance of the various cultivars used by local producers (Ledo et al., 1999). This fact, associated with the low technological level of the production system and planting of non-adapted genotypes, is a limiting factor for orange productivity (Silva et al., 2017).

The yield and quality of sweet orange fruits are associated with factors such as soil fertility, fertilization management, pest and disease control, water regime, irrigation practices, and use of superior adapted genotypes (Carvalho et al., 2020). Thus, the diversification of genetic materials and combinations of canopy and rootstock can contribute to increased fruit yield and quality (Carvalho et al., 2019).

In this sense, Embrapa Acre, aiming to enhance the cultivation of sweet orange crops in the Acre State, has been selecting genetic materials in the field, seeking potentially productive plants with quality fruits that are superior to those already found in the region, and has consequently expanded the number of cultivars recommended for the region (Negreiros et al., 2014).

This selection was initiated by Gondim et al. (2001), who carried out expeditions in nine municipalities in Acre State, Brazil, and collected the vegetative buds of 54 genotypes from local matrices and propagated seeds. The selected genotypes were evaluated in 2002 in the experimental field of Embrapa Acre; from this first group, 19 genotypes, as they presented the best productive indicators, were selected for this trial.

The objective of this study was to evaluate the productive performance and fruit quality of 20 sweet orange genotypes in three consecutive harvests under the edaphoclimatic conditions of the Acre State.

\section{Materials and Methods}

The experiment was conducted over three consecutive years $(2010,2011$, and 2012) at the Experimental Field of
Embrapa Acre, Rio Branco, AC, Brazil (1001'49"S, 67ㄴ1'08”'W, altitude of $159 \mathrm{~m}$ ). The local climate, according to Köppen's classification, is of the Am type: tropical monsoon, with annual rainfall ranging between 1,900 and 2,200 $\mathrm{mm}$ and average temperatures between 24 and $26^{\circ} \mathrm{C}$ (Alvares et al., 2013), and relative air humidity of approximately $83 \%$ (Inmet, 2019). The monthly average temperature and monthly average precipitation data during the trial evaluation period are shown in Figure 1.

The soil in the experimental area is classified as Oxisol (with a medium clayey texture and is well drained (Santos et al., 2018). Before the installation of the experiment, a chemical analysis of the soil was carried out (up to $0.4 \mathrm{~m}$ in depth), indicating the following characteristics: $\mathrm{pH}$ (in $\mathrm{H}_{2} \mathrm{O}$ ) of $5.2 ; 0.17 \mathrm{cmol} \mathrm{kg}^{-1}$ of $\mathrm{K} ; 3.70 \mathrm{cmol} \mathrm{dm}^{-3}$ of $\mathrm{Ca} ; 1.49 \mathrm{cmol} \mathrm{dm}^{-3}$ of Mg; $0.14 \mathrm{cmol} \mathrm{dm}^{-3}$ of Al; $2.57 \mathrm{cmol} \mathrm{dm}^{-3}$ of $\mathrm{H}+\mathrm{Al} ; 7.27 \mathrm{~g}$ $\mathrm{kg}^{-1}$ of organic carbon; CTC of $5.5 \mathrm{cmol}_{\mathrm{c}} \mathrm{dm}^{-3}$ and $68 \%$ base saturation (Negreiros et al., 2014).

The experiment was set up in February 2000, at $8.0 \times 8.0 \mathrm{~m}$ spacing, in randomized blocks, with 55 treatments and three replications using one plant per replication (Gondim et al., 2001). However, in the present study, 19 genotypes of sweet orange trees were considered, at 10 years of age, multiplied by grafting on the 'Rangpur' lime (Citrus limonia Osb.), in addition to the Aquiri cultivar recommended for the Acre State (Ledo et al., 1997). These genotypes, identified by the labels from previous field work, were selected from nine municipalities in Acre, Plácido de Castro (genotypes 4, 6, and 8), Senador Guiomard (genotypes 9, 11, and 13), Capixaba (genotypes 19 and 22), Xapuri (genotypes 24 and 25), Sena Madureira (genotypes 33 and 38), Brasiléia (genotypes 39 and 40), Epitaciolândia (genotypes 44, 46, and 47), Porto Acre (genotypes 49 and 52), and the local Aquiri cultivar of Rio Branco (Gondim et al., 2001).

The harvest time of most of these genotypes was distributed betwen March to August, concentrated in the months between April to July. In addition to the genotypes already identified by Gondim et al. (2001), they can be classified as early (genotype 8), mid-season (genotypes 4, 6, 11, 19, 24, $25,33,39,40,46,47,49$, and Aquiri cultivar), late (genotypes 13,22 , and 38 ), and continuous (genotypes 9,44 , and 52 ). The

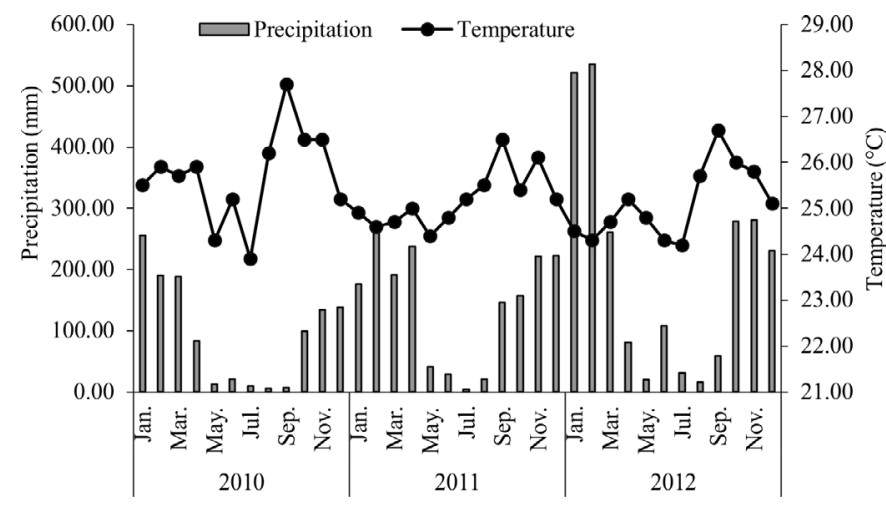

Source: Embrapa Acre meteorological station (2017).

Figure 1. Monthly average precipitation $(\mathrm{mm})$ and monthly average temperature $\left({ }^{\circ} \mathrm{C}\right)$ occurred in Rio Branco, AC, Brazil, during the experiment period. 
crop was managed following the recommendations of Ledo et al. (1997), for citrus cultivation under rainfed conditions.

During three consecutive harvests (2010, 2011, and 2012), the productive characteristics and quality of the fruits were evaluated, that is, the number of fruits per plant, fruit mass, production per plant, productivity, longitudinal fruit diameter, transversal fruit diameter, juice yield, peel thickness, soluble solids (SS), titratable acidity (TA), SS/TA (ratio), and technological index (TI).

Fruit mass and juice yield were determined by weighing on a precision scale, and the peel thickness was measured using a digital caliper. Soluble solids, in ${ }^{\circ}$ Brix, were determined by direct reading using a digital pocket refractometer. The titratable acidity of the juice was determined by titration with a $0.1 \mathrm{~N}$ $\mathrm{NaOH}$ solution and phenolphthalein indicator (AOAC, 2012). The ratio was determined by the SS/TA ratio, and the technological index (TI) was calculated according to Fadel et al. (2018):

$$
\mathrm{TI}=\text { juice yield } \times \text { soluble solids } \times 40.8 \times 10000
$$

where: 40.8 refers to the standard weight $(\mathrm{kg})$ of the orange harvest box.
The data obtained were submitted to the normality of residuals and homogeneity of variance tests. Next, joint analysis and individual per year ( $F$ test) were performed at $5 \%$ probability, and when the $F$ test showed significance, the means were compared using the Scott-Knott test at $5 \%$ probability. The correlation between the productives and fruit variables was determined and presented graphically in a correlation network using Rbio software (Bhering, 2017); as well as cluster analysis using the Ward method with Mahalanobis distance, using Genes software (Cruz, 2013), for the delineation of groups of genotypes that presented similar characteristics.

\section{Results and Discussion}

The individual and joint analysis of data from the three harvests revealed a significant effect of the $F$ test at $5 \%$ probability for all characteristics analyzed (Table 1). The isolated effects of years and genotypes on the production and fruit quality of sweet orange genotypes, and interactions between genotype and year for the circumference and mean diameter of the fruits were observed (Table 1).

Table 1. Joint analysis of the number of fruits per plant (NFP), fruit mass (FM), yield per plant (YPP), yield (Y), longitudinal fruit diameter (LFD), transversal fruit diameter (TFD), juice yield (JY), peel thickness (PT), soluble solids (SS), titratable acidity (TA), ratio (SS/TA) and technological index (TI) of 19 sweet orange genotypes, and Aquiri cultivar, evaluated for three consecutive years in the Acre State, Brazil.

\begin{tabular}{|c|c|c|c|c|c|c|c|c|c|c|c|c|c|}
\hline Source & DF & NFP & $\begin{array}{l}\text { FM } \\
\text { (g) }\end{array}$ & $\begin{array}{c}\text { YPP } \\
\left(\text { kg plant }^{-1}\right)\end{array}$ & $\begin{array}{c}\mathrm{Y} \\
(\mathrm{t} \mathrm{ha-1})\end{array}$ & \multicolumn{2}{|c|}{$(\mathrm{mm})$} & $\begin{array}{l}\text { JY } \\
(\%)\end{array}$ & \multirow{2}{*}{$\begin{array}{c}\begin{array}{c}\text { PT } \\
(\mathrm{mm})\end{array} \\
8.31^{*}\end{array}$} & \multirow{2}{*}{$\begin{array}{c}\begin{array}{c}\text { SS } \\
\text { ('Brix) }\end{array} \\
10.7^{*}\end{array}$} & \multirow{2}{*}{$\frac{\text { TA }}{0.26^{*}}$} & \multirow{2}{*}{$\begin{array}{c}\begin{array}{c}\text { SS/TA } \\
\text { ratio }\end{array} \\
72.8^{*}\end{array}$} & \multirow{2}{*}{$\frac{\mathrm{TI}}{1.8^{*}}$} \\
\hline $\operatorname{Year}(\mathrm{Y})$ & 2 & 10253168* & $11323.3^{*}$ & $331580.7^{*}$ & $8069.4^{*}$ & $43.6^{* *}$ & $190.46^{*}$ & 547.88* & & & & & \\
\hline Genotype (G) & 19 & $282570.5 *$ & $2079.1^{*}$ & $17873.1^{*}$ & $434.9 *$ & 103.9* & 83.97* & $59.28^{*}$ & $0.82^{*}$ & $1.21^{*}$ & $0.08^{*}$ & $16.2^{*}$ & $0.08 *$ \\
\hline$Y \times G$ & 38 & $102420.8^{\text {ns }}$ & $401.2^{\mathrm{ns}}$ & $4857.8^{\text {ns }}$ & $118.2^{\text {ns }}$ & $39.7^{*}$ & $39.24^{*}$ & $18.27^{\mathrm{ns}}$ & $0.28^{\text {ns }}$ & $0.28^{\text {ns }}$ & $0.009^{n s}$ & $1.26^{\mathrm{ns}}$ & $0.035^{\text {ns }}$ \\
\hline Bloc & 2 & $44067.7^{\text {ns }}$ & $5314.6^{*}$ & $5081.6^{\mathrm{ns}}$ & $123.7^{\text {ns }}$ & $143.5^{*}$ & $175.79 *$ & $80.58^{\text {ns }}$ & $0.06^{\text {ns }}$ & $0.07^{n s}$ & $0.012^{\text {ns }}$ & $4.43^{\text {ns }}$ & $0.08^{\text {ns }}$ \\
\hline Residual & 118 & 133917 & 435.7 & 5909.9 & 143.8 & 15.6 & 15.4 & 19.74 & 0.46 & 0.32 & 0.008 & 2.19 & 0.04 \\
\hline Mean & & 945.28 & 203.34 & 189.35 & 29.53 & 70.65 & 71.56 & 47.62 & 4.01 & 8.46 & 0.8 & 10.86 & 1.64 \\
\hline CV (\%) & & 38.71 & 10.27 & 40.6 & 40.6 & 5.58 & 5.48 & 9.33 & 17.09 & 6.65 & 11.2 & 13.62 & 12.32 \\
\hline \multirow{3}{*}{$\begin{array}{c}\text { Year/ } \\
\text { harvest }\end{array}$} & 2010 & $1352.5 \mathrm{a}$ & $193.79 \mathrm{~b}$ & $264.96 \mathrm{a}$ & $41.33 \mathrm{a}$ & $70.23 b$ & $72.74 \mathrm{a}$ & $47.65 b$ & $3.92 b$ & $8.18 b$ & $0.74 c$ & $11.24 \mathrm{a}$ & $1.59 \mathrm{~b}$ \\
\hline & 2011 & $957.3 \mathrm{~b}$ & $197.15 \mathrm{~b}$ & 186.7 b & $29.13 b$ & $70.09 \mathrm{~b}$ & $69.51 \mathrm{~b}$ & $44.59 \mathrm{c}$ & $4.41 \mathrm{a}$ & $8.26 \mathrm{~b}$ & $0.87 a$ & $9.62 \mathrm{~b}$ & $1.51 \mathrm{c}$ \\
\hline & 2012 & $526.0 \mathrm{c}$ & $219.08 a$ & $116.35 \mathrm{c}$ & $18.15 \mathrm{c}$ & $71.63 \mathrm{a}$ & $72.42 \mathrm{a}$ & 50.63 a & $3.67 \mathrm{~b}$ & $8.95 a$ & $0.78 b$ & $11.72 \mathrm{a}$ & $1.84 \mathrm{a}$ \\
\hline \multirow{20}{*}{$\begin{array}{l}\text { Mean of } \\
\text { genotype }\end{array}$} & 4 & 1029.0 a & 208.4 a & $204.6 \mathrm{a}$ & 31.9 a & $70.6 b$ & $62.3 d$ & $46.17 \mathrm{~b}$ & $4.4 a$ & 9.1 a & $0.71 d$ & $13.0 \mathrm{a}$ & $1.72 \mathrm{a}$ \\
\hline & 6 & $1287.0 \mathrm{a}$ & $221.5 \mathrm{a}$ & $288.2 \mathrm{a}$ & $44.9 a$ & $73.8 \mathrm{a}$ & $72.6 \mathrm{a}$ & $45.29 \mathrm{~b}$ & $4.2 \mathrm{a}$ & $8.5 a$ & $0.68 e$ & 12.7 a & $1.59 a$ \\
\hline & 8 & $1048.3 \mathrm{a}$ & $203.1 \mathrm{a}$ & $213.2 \mathrm{a}$ & $33.2 \mathrm{a}$ & $72.1 \mathrm{a}$ & $74.2 \mathrm{a}$ & $45.96 \mathrm{~b}$ & $3.8 \mathrm{~b}$ & 9.0 a & 0.67 e & $13.4 \mathrm{a}$ & $1.68 \mathrm{a}$ \\
\hline & 9 & 949.3 a & $215.2 \mathrm{a}$ & $199.2 \mathrm{a}$ & $31.0 \mathrm{a}$ & $72.5 \mathrm{a}$ & $72.6 \mathrm{a}$ & $47.10 \mathrm{~b}$ & $4.6 \mathrm{a}$ & $8.3 b$ & $0.80 \mathrm{c}$ & $10.4 \mathrm{~b}$ & $1.60 \mathrm{a}$ \\
\hline & 11 & $872.3 \mathrm{~b}$ & 195.2 b & 167.7 b & $26.1 \mathrm{~b}$ & $69.8 \mathrm{~b}$ & $74.4 \mathrm{a}$ & $45.63 \mathrm{~b}$ & 3.9 a & $9.1 \mathrm{a}$ & $0.89 \mathrm{~b}$ & $10.4 \mathrm{~b}$ & $1.70 \mathrm{a}$ \\
\hline & 13 & $1025.2 \mathrm{a}$ & 204.8 a & $211.5 \mathrm{a}$ & $33.0 \mathrm{a}$ & 70.7 b & 70.7 b & 50.05 a & $3.8 b$ & $8.2 b$ & $0.83 c$ & $9.96 \mathrm{c}$ & $1.69 \mathrm{a}$ \\
\hline & 19 & 994.0 a & $224.0 \mathrm{a}$ & $215.3 \mathrm{a}$ & $33.5 \mathrm{a}$ & 73.8 a & 72.7 a & $47.30 \mathrm{~b}$ & $4.1 \mathrm{a}$ & $8.2 b$ & $0.77 d$ & $10.9 \mathrm{~b}$ & $1.58 \mathrm{a}$ \\
\hline & 22 & $632.7 b$ & $226.5 \mathrm{a}$ & $139.9 \mathrm{~b}$ & $21.8 \mathrm{~b}$ & $75.2 \mathrm{a}$ & $73.0 \mathrm{a}$ & 52.01 a & $3.8 \mathrm{~b}$ & $8.2 b$ & $1.02 \mathrm{a}$ & $8.12 d$ & $1.74 \mathrm{a}$ \\
\hline & 24 & & & & & & & $46.53 \mathrm{~b}$ & & & & $b$ & $1.65 \mathrm{a}$ \\
\hline & 25 & $672.3 b$ & 195.8 b & $125.4 \mathrm{~b}$ & $19.5 \mathrm{~b}$ & $61.7 c$ & $70.4 \mathrm{~b}$ & $49.86 a$ & $3.4 b$ & $8.4 b$ & $0.88 b$ & $9.68 c$ & $1.71 \mathrm{a}$ \\
\hline & 33 & $677.0 \mathrm{~b}$ & & & & $62.3 c$ & & $53.43 \mathrm{a}$ & $3.5 b$ & 7.9 b & $0.90 \mathrm{~b}$ & $8.89 \mathrm{~d}$ & $1.73 \mathrm{a}$ \\
\hline & 38 & $849.5 b$ & 207.3 a & $174.6 \mathrm{~b}$ & $27.2 \mathrm{~b}$ & $72.7 \mathrm{a}$ & 72.8 a & $48.61 b$ & $4.2 \mathrm{a}$ & 8.7 a & $0.89 b$ & $9.87 \mathrm{C}$ & $1.73 \mathrm{a}$ \\
\hline & 39 & & $188.4 \mathrm{~b}$ & & $27.0 \mathrm{~b}$ & $68.9 \mathrm{~b}$ & $70.7 \mathrm{~b}$ & $47.28 \mathrm{~b}$ & $4.1 \mathrm{a}$ & $7.8 \mathrm{~b}$ & $0.86 b$ & $10.4 \mathrm{~b}$ & $1.71 \mathrm{a}$ \\
\hline & 40 & $1191.1 \mathrm{a}$ & 207.7 a & $248.1 \mathrm{a}$ & 38.7 a & 73.7 a & 73.9 a & $41.07 b$ & $4.1 \mathrm{a}$ & $8.8 \mathrm{a}$ & 0.62 e & $12.7 \mathrm{a}$ & $1.32 b$ \\
\hline & 44 & $962.8 \mathrm{a}$ & $185.9 \mathrm{~b}$ & $179.4 \mathrm{~b}$ & $27.9 \mathrm{~b}$ & $70.1 \mathrm{~b}$ & 70.1 b & $46.92 \mathrm{~b}$ & $3.6 b$ & $8.3 \mathrm{~b}$ & $0.79 \mathrm{c}$ & 10.7 b & $1.60 \mathrm{a}$ \\
\hline & 46 & $790.1 \mathrm{~b}$ & 199.4 b & $147.4 \mathrm{~b}$ & $22.9 \mathrm{~b}$ & $71.7 \mathrm{a}$ & 72.9 a & $47.55 \mathrm{~b}$ & $4.1 \mathrm{a}$ & $8.3 \mathrm{~b}$ & $0.81 \mathrm{c}$ & $10.5 \mathrm{~b}$ & $1.61 \mathrm{a}$ \\
\hline & 47 & 1094.7 a & $192.4 \mathrm{~b}$ & $212.8 \mathrm{a}$ & $33.2 \mathrm{a}$ & 69.2 b & $70.0 \mathrm{~b}$ & $48.18 b$ & $4.2 \mathrm{a}$ & $8.1 b$ & $0.73 d$ & $11.2 \mathrm{~b}$ & $1.60 \mathrm{a}$ \\
\hline & 49 & $940.4 \mathrm{a}$ & $195.8 \mathrm{~b}$ & $181.5 \mathrm{~b}$ & $28.3 b$ & $71.0 \mathrm{~b}$ & $69.6 \mathrm{~b}$ & $48.23 \mathrm{~b}$ & $3.5 b$ & $8.1 b$ & $0.73 d$ & $11.1 \mathrm{~b}$ & $1.60 \mathrm{a}$ \\
\hline & 52 & $1080.5 \mathrm{a}$ & $212.2 \mathrm{a}$ & $222.5 \mathrm{a}$ & $34.7 \mathrm{a}$ & $72.1 \mathrm{a}$ & 71.6 b & $47.90 \mathrm{~b}$ & $4.2 \mathrm{a}$ & $8.3 b$ & $0.76 d$ & $11.1 \mathrm{~b}$ & $1.64 \mathrm{a}$ \\
\hline & Aquiri & 1109.6 a & $223.1 \mathrm{a}$ & $235.7 \mathrm{a}$ & $36.7 \mathrm{a}$ & $70.6 \mathrm{~b}$ & $74.3 \mathrm{a}$ & $47.39 \mathrm{~b}$ & $3.8 \mathrm{~b}$ & $8.7 \mathrm{a}$ & $0.80 \mathrm{c}$ & $10.9 \mathrm{~b}$ & $1.68 \mathrm{a}$ \\
\hline
\end{tabular}

Means followed by equal letters in the column do not differ by the Skott-Knott test at $5 \%$ probability; CV\%: coefficient of variation; ns: not significant; * significant at $5 \%$ by $\mathrm{F}$ test. 
Regarding the effect of years, it was found that the best production indicators were obtained in the 2010 harvest. The harvest for that year had the highest number of fruits per plant (1,352.50), production per plant $(264.96 \mathrm{~kg})$, and productivity (41.33 $\mathrm{t} \mathrm{ha}^{-1}$ ), which corresponded to respective increases of 61,52 , and $56 \%$ over the 2012 harvest, which had the lowest rates. On the other hand, the mass and transversal diameter of the fruits, as well as the juice yield, were higher in 2012, showing negative correlations with the production indicators. These results may be associated with the distinct climatic conditions that occurred, particularly in precipitation, which was higher in 2012.

Although the appearance of the fruit has been considered important, mainly for fresh consumption, the ratio, technological index, and fruit juice yield are the most important factors examined when selecting genotypes.

The peel thickness ranged from $3.62 \mathrm{~mm}$ in 2012 to 4.41 $\mathrm{mm}$ in 2011. This morphological characteristic is important for the selection of new cultivars, as it is directly related to transport resistance and juice yield. Fruits with thin skin can suffer mechanical damage during transport; however, they have increased juice yield and are preferred for fresh consumption, given the facility of peeling.

Characteristics such as the number of fruits per plant (NFP) and yield per plant (YPP) were positively correlated with total fruit yield (Y) (Gonçalves et al., 2018). However, the annual reduction in NFP and TFY favored an increase in fruit mass (FM) and longitudinal fruit diameter (LFD), which was significantly higher in 2012 (Table 1).

In addition to the productive characteristics, qualitative variables for the fruits, the soluble solids (SS) and ratio (SS/TA) were also higher in 2012 . The smaller amount of fruits present in the plants in 2012 may have increased the SS content and TA ratio, by reducing competition for photoassimilates, relative to previous years.

Kirinus et al. (2019) reported that, in early years, the development of sweet orange plants may be influenced by the environmental characteristics of the cultivation site, in addition to the type of canopy and rootstock used; these can determine whether fruits ripen early, middle, or late in the season. On the other hand, Beber et al. (2018) reported that the use of the same rootstock for different genotypes can ensure low variabilities in production. Studies evaluating different rootstocks are important for the material selection process because this factor directly influences the production performance of the crop.

The total acidity ranged from $0.74 \%$ in 2010 to $0.87 \%$ in 2011 , which is considered adequate for table oranges $(0.6 \%$ to $0.9 \%)$. Variations in total acidity levels are recurrent, as they are easily altered by climatic factors or crop management. Citric acid is the main organic acid found in orange juice and is responsible for total acidity. This organic acid participates in the Krebs respiratory cycle and can be converted to sugars during this metabolic process. Thus, high-temperature peaks during the fruit maturation phase (stage III) can reduce this compound in the fruit.
Legua et al. (2013) reported that soluble solids and titratable acidity are important parameters that serve as references for sweet orange fruits quality, and that the relationship between them is the best indicator to estimate the physiological maturity level of the fruits. Low ratio values, such as those found in genotypes 13,25 , and 38 , may indicate that they were not yet suitable for harvesting, with the characteristics of unripe fruits; because, according to Teodoro et al. (2020), early harvests affect the quality of the fruit, resulting in poor juice quality. When harvested at a appropriate time, suitable ratio values are obtained.

The technological index, or amount of total soluble solids per $40.8 \mathrm{~kg}$ box, was significantly higher in 2012 , reaching the value of $1.8 \mathrm{~kg}$ per box, followed by 2010 and 2011, at 1.59 and $1.51 \mathrm{~kg}$ per box, respectively. These results are associated with the increase in the average total soluble solids in the fruits harvested in the 2012 harvest, which was $8.6 \%$ higher than the 2010 harvest and 8.4\% higher than that in 2011. Soluble solids and titratable acidity are directly linked to the concentration of sugars and citric acid in the fruits; therefore, together with the ratio, they are essential qualitative indicators in the selection of new cultivars.

Genetic variability was found between the the genotypes of each harvest (Table 2), especially for acidity, soluble solids, and ratio. Few variations were observed among the genotypes for the production variables: number of fruits per plant, average fruit mass, productivity per hectare, longitudinal fruit diameter, transversal fruit diameter, and juice yield.

In the 2010 harvest, of the 12 variables evaluated, only fruit mass, longitudinal fruit diameter, transversal fruit diameter, and titratable acidity were influenced by the genotype. There was no effect on the number of fruits per plant, production per plant, yield, juice yield, peel thickness, soluble solids, titratable acidity, or ratio. For the following year, 2011, there were variations only in the content of soluble solids, titratable acidity, ratio, longitudinal fruit diameter and transversal fruit diameter. For the 2012 harvest, 50\% of the variables were influenced by genotypes, with no effect on the number of fruits per plant, production per plant, productivity, juice yield, peel thickness, or technological index.

In general, in the 2010 harvest, genotypes 6, 9, 19, and 40 , and the Aquiri cultivar showed the best productive and fruit quality characteristics; in the 2011 harvest, the best results were obtained with genotypes 6 and 8 and in 2012, with genotypes 6,8 , and 4 . Thus, it appears that genotype 6 presents the desirable characteristics of an suitable cultivar, with appropriate productivity, over the years, with fruits that meet the standard of quality demanded by the consumer market; similar to the Aquiri cultivar, which is recommended for the Acre State, Brazil.

Costa et al. (2018) reported that the fruit yield and its respective quality characteristics are essential factors that must be analyzed during the selection of new cultivars, and that they must meet the standards established by the industry, as well as fresh consumption, according to consumer requirements. Of the 19 genotypes, in addition to the Aquiri 
Table 2. Number of fruits per plant (NFP), fruit mass (FM), yield per plant (YPP), yield (Y), longitudinal fruit diameter (LFD), transversal fruit diameter (TFD), juice mass (JM), peel thickness (PT), soluble solids (SS), titratable acidity (TA), ratio (SS/TA) and technological index (TI) of 19 sweet orange genotypes, and Aquiri cultivar, evaluated for three consecutive years (2010, 2011 and 2012) in the Acre State, Brazil.

\begin{tabular}{|c|c|c|c|c|c|c|c|c|c|c|c|c|}
\hline \multirow{2}{*}{ Genotype } & \multirow{2}{*}{ NFP } & \multirow{2}{*}{$\begin{array}{l}F M \\
\text { (g) }\end{array}$} & \multirow{2}{*}{$\begin{array}{c}\text { YPP } \\
\left(\text { kg plant }^{-1}\right)\end{array}$} & \multirow{2}{*}{$\begin{array}{c}Y \\
\left(t \mathrm{ha}^{-1}\right)\end{array}$} & LFD & TFD & \multirow{2}{*}{$\begin{array}{c}\text { JM (10 fruits) } \\
\text { (g) }\end{array}$} & \multirow{2}{*}{$\begin{array}{c}\text { PT } \\
(\mathrm{mm})\end{array}$} & \multirow{2}{*}{$\begin{array}{c}\text { SS } \\
\text { ('Brix) }\end{array}$} & \multirow{2}{*}{$\begin{array}{l}\text { TA } \\
(\%)\end{array}$} & \multirow{2}{*}{$\begin{array}{c}\text { SS/TA } \\
\text { ratio }\end{array}$} & TT \\
\hline & & & & & & & & & & & & II \\
\hline & & & & & 20 & & & & & & & \\
\hline 4 & $1507.00 \mathrm{a}$ & $184.41 \mathrm{~b}$ & $283.01 \mathrm{a}$ & $44.15 \mathrm{a}$ & $67.32 \mathrm{~b}$ & $70.67 b$ & $816.96 \mathrm{a}$ & $4.20 a$ & $9.00 \mathrm{a}$ & $0.65 c$ & $13.79 \mathrm{a}$ & $1.64 \mathrm{a}$ \\
\hline 6 & $1604.33 \mathrm{a}$ & $219.956 \mathrm{a}$ & $352.95 \mathrm{a}$ & $55.06 \mathrm{a}$ & $74.59 \mathrm{a}$ & $76.63 \mathrm{a}$ & $933.00 \mathrm{a}$ & $4.15 \mathrm{a}$ & $7.90 \mathrm{a}$ & $0.60 \mathrm{c}$ & $13.04 \mathrm{a}$ & $1.37 \mathrm{a}$ \\
\hline 8 & $1417.33 \mathrm{a}$ & $197.426 \mathrm{~b}$ & $286.76 \mathrm{a}$ & $44.73 \mathrm{a}$ & $72.75 a$ & $74.96 \mathrm{a}$ & $899.40 \mathrm{a}$ & $4.04 \mathrm{a}$ & $8.70 a$ & $0.65 \mathrm{c}$ & $13.37 \mathrm{a}$ & $1.61 \mathrm{a}$ \\
\hline 9 & $1307.66 \mathrm{a}$ & 204.136 a & $267.35 \mathrm{a}$ & $41.70 \mathrm{a}$ & $72.33 a$ & $74.59 a$ & $978.70 \mathrm{a}$ & $4.13 \mathrm{a}$ & $8.10 a$ & $0.76 \mathrm{c}$ & $10.75 a$ & $1.58 \mathrm{a}$ \\
\hline 11 & $1259.33 \mathrm{a}$ & $190.56 \mathrm{~b}$ & $238.26 a$ & $37.17 \mathrm{a}$ & $67.69 \mathrm{~b}$ & $71.91 b$ & $906.30 \mathrm{a}$ & $3.74 \mathrm{a}$ & $9.13 \mathrm{a}$ & $0.78 c$ & $12.01 \mathrm{a}$ & $1.77 \mathrm{a}$ \\
\hline 13 & $1325.00 \mathrm{a}$ & $194.583 b$ & $258.50 \mathrm{a}$ & $40.32 \mathrm{a}$ & $70.23 a$ & $73.84 \mathrm{a}$ & $985.63 \mathrm{a}$ & $4.03 \mathrm{a}$ & $7.40 \mathrm{a}$ & $0.75 \mathrm{c}$ & $9.78 \mathrm{a}$ & $1.52 \mathrm{a}$ \\
\hline 19 & $1470.33 \mathrm{a}$ & $203.023 \mathrm{a}$ & $304.96 \mathrm{a}$ & $47.57 \mathrm{a}$ & $72.47 a$ & $74.41 \mathrm{a}$ & $952.90 \mathrm{a}$ & $3.99 a$ & $7.66 \mathrm{a}$ & $0.71 \mathrm{c}$ & $11.09 a$ & $1.48 \mathrm{a}$ \\
\hline 22 & $917.33 \mathrm{a}$ & $221.966 \mathrm{a}$ & $200.90 \mathrm{a}$ & $31.34 \mathrm{a}$ & $73.97 a$ & $75.85 a$ & $1109.33 \mathrm{a}$ & $3.61 \mathrm{a}$ & $8.16 a$ & $1.06 \mathrm{a}$ & $7.72 \mathrm{a}$ & $1.66 \mathrm{a}$ \\
\hline 24 & $1233.33 \mathrm{a}$ & $177.433 \mathrm{~b}$ & $214.36 a$ & $33.44 a$ & $67.12 \mathrm{~b}$ & $68.46 b$ & 837.43 a & $3.62 \mathrm{a}$ & $8.20 \mathrm{a}$ & $0.75 \mathrm{c}$ & $10.92 a$ & $1.57 \mathrm{a}$ \\
\hline 25 & $760.66 \mathrm{a}$ & $169.463 b$ & $128.33 \mathrm{a}$ & $20.02 a$ & $67.16 \mathrm{~b}$ & $69.08 \mathrm{~b}$ & $885.06 \mathrm{a}$ & $3.25 \mathrm{a}$ & $8.00 \mathrm{a}$ & $0.82 \mathrm{c}$ & $9.65 a$ & $1.70 \mathrm{a}$ \\
\hline 33 & $880.00 a$ & $165.21 \mathrm{~b}$ & $138.90 \mathrm{a}$ & $21.67 a$ & $62.52 \mathrm{~b}$ & $67.58 b$ & $846.06 \mathrm{a}$ & $3.44 a$ & $7.33 a$ & $0.78 c$ & $9.47 a$ & $1.52 \mathrm{a}$ \\
\hline 38 & $1077.33 \mathrm{a}$ & 194.87 b & $211.33 \mathrm{a}$ & $32.97 \mathrm{a}$ & $70.20 a$ & $72.99 \mathrm{~b}$ & $979.43 a$ & $3.98 a$ & $9.00 \mathrm{a}$ & $0.86 \mathrm{~b}$ & $10.41 \mathrm{a}$ & $1.84 \mathrm{a}$ \\
\hline 39 & $1458.00 \mathrm{a}$ & $174.21 b$ & $252.74 a$ & $39.43 a$ & $67.13 \mathrm{~b}$ & $71.78 b$ & $827.16 \mathrm{a}$ & $3.84 \mathrm{a}$ & $8.66 a$ & $0.76 \mathrm{c}$ & $11.55 \mathrm{a}$ & $1.68 \mathrm{a}$ \\
\hline 40 & $1506.00 \mathrm{a}$ & 216.37 a & $440.59 \mathrm{a}$ & $68.73 a$ & $76.10 a$ & $76.89 a$ & $908.69 \mathrm{a}$ & $3.97 \mathrm{a}$ & $7.46 \mathrm{a}$ & $0.59 \mathrm{c}$ & $12.64 \mathrm{a}$ & $1.28 \mathrm{a}$ \\
\hline 44 & $1287.00 \mathrm{a}$ & $182.28 \mathrm{~b}$ & $274.07 a$ & $42.75 a$ & $70.31 a$ & $70.87 b$ & $833.93 \mathrm{a}$ & $3.91 \mathrm{a}$ & $8.33 a$ & $0.74 \mathrm{c}$ & $11.37 a$ & $1.54 \mathrm{a}$ \\
\hline 46 & $1575.66 \mathrm{a}$ & $181.293 b$ & 230.27 a & $35.92 \mathrm{a}$ & $69.70 \mathrm{a}$ & $72.33 \mathrm{~b}$ & 884.20 a & $4.16 \mathrm{a}$ & $7.83 a$ & $0.72 \mathrm{c}$ & $11.12 \mathrm{a}$ & $1.56 \mathrm{a}$ \\
\hline 47 & $1359.00 \mathrm{a}$ & $185.013 b$ & 309.88 a & $48.34 a$ & $69.65 a$ & $71.32 b$ & $878.60 \mathrm{a}$ & $4.22 \mathrm{a}$ & $8.16 a$ & $0.68 c$ & $12.21 \mathrm{a}$ & $1.57 \mathrm{a}$ \\
\hline 49 & $1570.00 \mathrm{a}$ & $187.863 b$ & $256.69 \mathrm{a}$ & $40.04 a$ & $71.17 a$ & $71.41 \mathrm{~b}$ & $934.73 \mathrm{a}$ & $3.76 \mathrm{a}$ & $8.00 \mathrm{a}$ & $0.69 \mathrm{c}$ & $11.58 \mathrm{a}$ & $1.62 \mathrm{a}$ \\
\hline 52 & $1504.33 \mathrm{a}$ & 207.696 a & 320.82 a & $50.05 a$ & $71.37 a$ & $72.90 \mathrm{~b}$ & $931.30 \mathrm{a}$ & $4.13 \mathrm{a}$ & $8.16 \mathrm{a}$ & $0.72 \mathrm{c}$ & $11.36 \mathrm{a}$ & $1.51 \mathrm{a}$ \\
\hline Aquiri & $2031.00 \mathrm{a}$ & $218.12 \mathrm{a}$ & $328.56 \mathrm{a}$ & $51.25 a$ & $70.81 \mathrm{a}$ & $76.35 a$ & $1099.16 \mathrm{a}$ & $4.22 \mathrm{a}$ & $8.50 \mathrm{a}$ & $0.77 \mathrm{c}$ & $10.97 \mathrm{a}$ & $1.75 \mathrm{a}$ \\
\hline & & & & & 20 & & & & & & & \\
\hline 4 & $1020.00 \mathrm{a}$ & 201.55 a & $201.22 \mathrm{a}$ & $31.39 a$ & $71.53 a$ & $71.70 \mathrm{a}$ & $898.24 \mathrm{a}$ & $5.06 \mathrm{a}$ & $8.86 \mathrm{a}$ & $0.83 a$ & $10.66 b$ & $1.60 \mathrm{a}$ \\
\hline 6 & $1421.66 \mathrm{a}$ & $217.30 \mathrm{a}$ & 309.04 a & $48.21 \mathrm{a}$ & $72.60 \mathrm{a}$ & $72.44 a$ & $951.07 \mathrm{a}$ & $4.53 \mathrm{a}$ & $8.56 a$ & $0.78 \mathrm{~b}$ & $11.02 \mathrm{a}$ & $1.51 \mathrm{a}$ \\
\hline 8 & $1150.00 \mathrm{a}$ & 187.59 a & $217.75 a$ & $33.96 a$ & $70.76 a$ & $69.78 a$ & $866.62 \mathrm{a}$ & $4.34 \mathrm{a}$ & $8.96 a$ & $0.74 \mathrm{~b}$ & $12.14 a$ & $1.69 \mathrm{a}$ \\
\hline 9 & $778.02 \mathrm{a}$ & 220.41 a & $164.85 \mathrm{a}$ & $25.71 \mathrm{a}$ & $73.16 a$ & $74.10 \mathrm{a}$ & $960.71 \mathrm{a}$ & $4.58 \mathrm{a}$ & $8.20 \mathrm{~b}$ & $0.82 \mathrm{~b}$ & $10.04 \mathrm{~b}$ & $1.45 \mathrm{a}$ \\
\hline 11 & 949.66 a & 194.14 a & $180.85 a$ & 28.21 a & $71.69 a$ & $70.48 a$ & $844.22 \mathrm{a}$ & $4.24 \mathrm{a}$ & $8.56 a$ & $0.96 a$ & $8.90 c$ & $1.51 \mathrm{a}$ \\
\hline 13 & $878.00 \mathrm{a}$ & $195.40 \mathrm{a}$ & $174.2 \mathrm{a}$ & $27.18 a$ & $71.13 a$ & $71.98 \mathrm{a}$ & $888.05 \mathrm{a}$ & $4.24 \mathrm{a}$ & $8.06 \mathrm{~b}$ & $0.82 \mathrm{~b}$ & $9.76 \mathrm{~b}$ & $1.49 a$ \\
\hline 19 & $842.00 \mathrm{a}$ & $223.82 \mathrm{a}$ & $176.75 a$ & $27.57 a$ & $75.34 a$ & $71.65 a$ & $932.82 \mathrm{a}$ & $4.83 a$ & $8.36 \mathrm{a}$ & $0.85 b$ & $9.83 b$ & $1.44 \mathrm{a}$ \\
\hline 22 & $645.66 \mathrm{a}$ & $208.90 \mathrm{a}$ & $135.70 \mathrm{a}$ & $21.16 \mathrm{a}$ & $75.90 \mathrm{a}$ & $75.03 \mathrm{a}$ & $1085.96 \mathrm{a}$ & $4.43 \mathrm{a}$ & $7.96 b$ & $1.10 \mathrm{a}$ & $7.29 \mathrm{~d}$ & $1.69 \mathrm{a}$ \\
\hline 24 & 614.01 a & $195.22 \mathrm{a}$ & $121.07 \mathrm{a}$ & $18.88 \mathrm{a}$ & $71.89 a$ & $70.48 a$ & 813. & $4.32 \mathrm{a}$ & $8.56 a$ & $0.81 \mathrm{~b}$ & $10.60 \mathrm{~b}$ & $1.46 \mathrm{a}$ \\
\hline 25 & 841.33 a & 189.65 a & $157.87 \mathrm{a}$ & $24.63 a$ & $45.35 \mathrm{~b}$ & $44.48 \mathrm{~b}$ & $844.46 \mathrm{a}$ & $3.97 \mathrm{a}$ & $8.70 \mathrm{a}$ & $1.02 \mathrm{a}$ & $8.67 \mathrm{c}$ & $1.58 \mathrm{a}$ \\
\hline 33 & $691.66 \mathrm{a}$ & $152.48 \mathrm{a}$ & $104.96 \mathrm{a}$ & $16.37 \mathrm{a}$ & $63.85 a$ & $66.37 a$ & $751.43 \mathrm{a}$ & $3.94 \mathrm{a}$ & $8.03 b$ & $1.06 \mathrm{a}$ & $7.58 d$ & $1.61 \mathrm{a}$ \\
\hline 38 & $941.33 \mathrm{a}$ & 206.35 a & $194.67 \mathrm{a}$ & $30.36 \mathrm{a}$ & $74.51 \mathrm{a}$ & $71.77 \mathrm{a}$ & 949.67 a & $4.61 \mathrm{a}$ & $8.40 a$ & $0.98 a$ & $8.59 c$ & $1.58 \mathrm{a}$ \\
\hline 39 & 936.66 a & 190.59 a & $177.63 \mathrm{a}$ & $27.71 \mathrm{a}$ & $70.22 a$ & $70.39 a$ & $866.01 \mathrm{a}$ & $4.58 \mathrm{a}$ & $8.53 a$ & $0.98 a$ & $8.78 c$ & $1.58 \mathrm{a}$ \\
\hline 40 & $1032.00 \mathrm{a}$ & 197.29 a & $198.30 \mathrm{a}$ & $30.93 a$ & $73.16 a$ & $71.83 a$ & $713.25 \mathrm{a}$ & $4.53 \mathrm{a}$ & $7.46 \mathrm{~b}$ & $0.65 \mathrm{~b}$ & $11.44 a$ & $1.11 \mathrm{a}$ \\
\hline 44 & 809.33 a & $187.65 \mathrm{a}$ & $147.28 \mathrm{a}$ & $22.98 a$ & $71.33 a$ & $70.45 a$ & $766.60 \mathrm{a}$ & $4.06 \mathrm{a}$ & $7.60 \mathrm{~b}$ & $0.82 \mathrm{~b}$ & $9.20 \mathrm{c}$ & $1.25 \mathrm{a}$ \\
\hline 46 & 759.33 a & $196.38 \mathrm{a}$ & $142.34 \mathrm{a}$ & $22.20 \mathrm{a}$ & $71.91 \mathrm{a}$ & $72.58 \mathrm{a}$ & $850.44 \mathrm{a}$ & $4.56 \mathrm{a}$ & $7.96 b$ & $0.86 \mathrm{~b}$ & $9.27 \mathrm{c}$ & $1.40 \mathrm{a}$ \\
\hline 47 & $1360.33 \mathrm{a}$ & $193.04 \mathrm{a}$ & $260.81 a$ & $40.68 \mathrm{a}$ & $67.76 a$ & $66.48 \mathrm{a}$ & $892.91 \mathrm{a}$ & $4.77 \mathrm{a}$ & $7.83 \mathrm{~b}$ & $0.77 b$ & $10.09 \mathrm{~b}$ & $1.47 \mathrm{a}$ \\
\hline 49 & 954.33 a & 196.00 a & $184.88 \mathrm{a}$ & $28.84 a$ & $70.99 a$ & $68.47 a$ & $864.04 \mathrm{a}$ & $4.25 \mathrm{a}$ & $7.86 \mathrm{~b}$ & $0.79 \mathrm{~b}$ & $9.92 b$ & $1.41 \mathrm{a}$ \\
\hline 52 & $1188.00 \mathrm{a}$ & 200.15 a & $234.65 \mathrm{a}$ & $36.60 \mathrm{a}$ & $70.09 a$ & $68.17 a$ & $991.03 \mathrm{a}$ & $4.50 \mathrm{a}$ & $8.03 \mathrm{~b}$ & $0.85 b$ & $9.48 c$ & $1.63 \mathrm{a}$ \\
\hline Aquiri & $1332.66 \mathrm{a}$ & $189.10 \mathrm{a}$ & $249.81 \mathrm{a}$ & $38.97 \mathrm{a}$ & $68.66 \mathrm{a}$ & $71.59 \mathrm{a}$ & $828.52 \mathrm{a}$ & $3.79 \mathrm{a}$ & $8.63 \mathrm{a}$ & $0.94 \mathrm{a}$ & $9.16 c$ & $1.54 \mathrm{a}$ \\
\hline & & & & & 20 & & & & & & & \\
\hline 4 & $560 a$ & 239.49 a & $129.68 \mathrm{a}$ & $20.22 a$ & $73.04 a$ & $75.62 a$ & $1198.44 \mathrm{a}$ & $3.96 \mathrm{a}$ & $9.43 \mathrm{a}$ & $0.65 b$ & $14.76 a$ & $1.92 \mathrm{a}$ \\
\hline 6 & $835 a$ & 227.46 a & & $31.61 \mathrm{a}$ & $74.43 a$ & $73.80 a$ & & $4.05 \mathrm{a}$ & $9.26 \mathrm{a}$ & $0.67 \mathrm{~b}$ & $14.08 \mathrm{a}$ & $1.87 \mathrm{a}$ \\
\hline 8 & $577 a$ & 224.35 a & $135.30 \mathrm{a}$ & $21.10 \mathrm{a}$ & $72.83 a$ & $73.17 \mathrm{a}$ & $1044.59 \mathrm{a}$ & $3.26 a$ & $9.33 \mathrm{a}$ & $0.63 \mathrm{~b}$ & $14.90 \mathrm{a}$ & $1.76 \mathrm{a}$ \\
\hline 9 & $762 a$ & & & & $72.29 a$ & $74.68 \mathrm{a}$ & & $5.17 \mathrm{a}$ & $8.70 \mathrm{~b}$ & $0.83 a$ & $10.46 \mathrm{~b}$ & $1.77 \mathrm{a}$ \\
\hline 11 & $408 a$ & $.97 \mathrm{~b}$ & & & $70.11 a$ & & & $8 a$ & $6 a$ & $0.94 \mathrm{a}$ & $\mathrm{Ob}$ & $1.81 \mathrm{a}$ \\
\hline 13 & $872 a$ & 224.63 a & $201.94 \mathrm{a}$ & $31.50 \mathrm{a}$ & $70.79 a$ & $72.40 \mathrm{a}$ & $1222.39 \mathrm{a}$ & $3.06 \mathrm{a}$ & $9.30 \mathrm{a}$ & $0.90 \mathrm{a}$ & $10.33 \mathrm{~b}$ & $2.05 \mathrm{a}$ \\
\hline 19 & $669 a$ & $245.15 \mathrm{a}$ & $164.29 a$ & $25.62 \mathrm{a}$ & $73.78 a$ & $73.14 a$ & $1288.17 \mathrm{a}$ & $3.60 \mathrm{a}$ & $8.56 b$ & $0.73 b$ & $11.87 \mathrm{~b}$ & $1.83 \mathrm{a}$ \\
\hline 22 & $335 \mathrm{a}$ & $248.69 \mathrm{a}$ & $83.11 \mathrm{a}$ & $12.97 \mathrm{a}$ & $5.76 \mathrm{a}$ & $75.42 \mathrm{a}$ & $1334.77 \mathrm{a}$ & $3.54 a$ & $8.60 \mathrm{~b}$ & $0.92 \mathrm{a}$ & $9.35 \mathrm{~b}$ & $1.89 \mathrm{a}$ \\
\hline 24 & $373 a$ & $211.44 \mathrm{~b}$ & $79.18 \mathrm{a}$ & $12.35 \mathrm{a}$ & $70.62 a$ & $72.40 \mathrm{a}$ & $1069.26 \mathrm{a}$ & $3.70 \mathrm{a}$ & $9.26 \mathrm{a}$ & $0.86 a$ & $10.88 \mathrm{~b}$ & $1.92 \mathrm{a}$ \\
\hline 25 & $415 \mathrm{a}$ & 228.29 a & $90.09 \mathrm{a}$ & $14.05 \mathrm{a}$ & $72.79 a$ & $73.60 \mathrm{a}$ & $1200.77 \mathrm{a}$ & $3.27 \mathrm{a}$ & $8.60 \mathrm{~b}$ & $0.80 \mathrm{a}$ & $10.71 b$ & $1.86 \mathrm{a}$ \\
\hline 33 & $459 a$ & $175.95 b$ & $80.29 a$ & $12.52 \mathrm{a}$ & $60.66 \mathrm{~b}$ & $64.47 b$ & $1051.74 \mathrm{a}$ & $3.30 \mathrm{a}$ & $8.41 b$ & $0.88 a$ & $9.62 b$ & $2.06 \mathrm{a}$ \\
\hline 38 & $530 a$ & $220.90 \mathrm{a}$ & $117.82 \mathrm{a}$ & $18.38 \mathrm{a}$ & $73.50 \mathrm{a}$ & $73.64 a$ & $1090.05 \mathrm{a}$ & $4.10 \mathrm{a}$ & $8.76 \mathrm{~b}$ & $0.83 a$ & $10.61 \mathrm{~b}$ & $1.77 \mathrm{a}$ \\
\hline 39 & $482 \mathrm{a}$ & $200.69 \mathrm{~b}$ & $89.12 \mathrm{a}$ & $13.90 \mathrm{a}$ & $69.53 a$ & $70.18 b$ & $986.74 \mathrm{a}$ & $4.13 \mathrm{a}$ & $9.36 \mathrm{a}$ & $0.86 a$ & $10.99 \mathrm{~b}$ & $1.87 \mathrm{a}$ \\
\hline 40 & $510 a$ & $209.61 \mathrm{~b}$ & $105.46 \mathrm{a}$ & $16.45 \mathrm{a}$ & $72.03 a$ & $72.97 \mathrm{a}$ & $957.50 \mathrm{a}$ & $3.84 \mathrm{a}$ & $8.60 \mathrm{~b}$ & $0.61 b$ & $14.04 \mathrm{a}$ & $1.58 \mathrm{a}$ \\
\hline 44 & $573 a$ & $188.05 \mathrm{~b}$ & $117.04 \mathrm{a}$ & 18.25 & $68.69 \mathrm{a}$ & $69.15 b$ & $1058.22 \mathrm{a}$ & $3.09 \mathrm{a}$ & $9.10 \mathrm{a}$ & $0.82 a$ & $11.54 \mathrm{~b}$ & $2.02 \mathrm{a}$ \\
\hline 46 & $324 a$ & 220.59 a & $69.59 \mathrm{a}$ & $10.85 a$ & $73.48 a$ & $73.79 a$ & $1116.09 \mathrm{a}$ & $3.72 \mathrm{a}$ & $9.10 a$ & $0.84 a$ & $11.37 \mathrm{~b}$ & $1.87 \mathrm{a}$ \\
\hline 47 & $348 a$ & $199.26 \mathrm{~b}$ & $67.92 \mathrm{a}$ & $10.59 \mathrm{a}$ & $70.18 a$ & $72.36 \mathrm{a}$ & $1020.62 a$ & $3.69 \mathrm{a}$ & $8.40 \mathrm{~b}$ & $0.74 \mathrm{~b}$ & $11.40 \mathrm{~b}$ & $1.76 \mathrm{a}$ \\
\hline 49 & $508 a$ & $203.80 \mathrm{~b}$ & $102.93 \mathrm{a}$ & $16.06 \mathrm{a}$ & $70.97 a$ & $69.00 \mathrm{~b}$ & $1041.90 \mathrm{a}$ & $2.62 \mathrm{a}$ & $8.53 b$ & $0.72 \mathrm{~b}$ & $12.00 \mathrm{~b}$ & $1.76 \mathrm{a}$ \\
\hline 52 & $483 a$ & $228.81 \mathrm{a}$ & $112.21 \mathrm{a}$ & $17.50 \mathrm{a}$ & $74.84 a$ & $73.76 \mathrm{a}$ & $1099.23 \mathrm{a}$ & $3.99 a$ & $8.93 \mathrm{~b}$ & $0.71 b$ & $12.59 \mathrm{a}$ & $1.76 \mathrm{a}$ \\
\hline Aquiri & $491 \mathrm{a}$ & $262.29 \mathrm{a}$ & $128.95 \mathrm{a}$ & $20.11 \mathrm{a}$ & $72.32 a$ & $75.02 \mathrm{a}$ & $1254.78 \mathrm{a}$ & $3.43 a$ & $9.03 a$ & $0.71 \mathrm{~b}$ & $12.72 \mathrm{a}$ & $1.76 \mathrm{a}$ \\
\hline
\end{tabular}

Means followed by equal letters in the column do not differ by Scott-Knott test at $5 \%$ probability. 
cultivar, $95 \%$ met the minimum values required by Normative Instruction number 37, of October 1, 2018, of the Ministry of Agriculture, Livestock and Supply (Brazil, 2018), with ratio values above 9.0 and an average fruit mass above $200 \mathrm{~g}$.

The averages of the joint analysis of data from the three consecutive harvests $(2010,2011$, and 2012) demonstrate that genotypes 6, 8, 9, and 52, as well as the cultivar Aquiri, are the ones with the best averages for the number of fruits per plant, production per plant, productivity, and technological index, showing high potential for launch as commercial cultivars in the state of Acre.

The genotypes mentioned above $(6,8,9,52)$ had an average yield of $35 \mathrm{t} \mathrm{ha}^{-1}$, productivity that is $26.3 \%$ higher than the average for the other genotypes. This yield is $21 \%$ higher than the national average $\left(29 \mathrm{t} \mathrm{ha}^{-1}\right), 37 \%$ higher than the average for the northern region $\left(20 \mathrm{t} \mathrm{ha}^{-1}\right)$ and $241 \%$ higher than the average for the state of Acre (15 t ha-1) (IBGE, 2019). In addition to adequate productive characteristics, these genotypes meet the Brazilian federal legislation for minimum fruit size, titratable acidity (Couto et al., 2018), soluble solids, and ratio (Brasil, 2018).

Although it presents good results in general, it is noteworthy that genotypes 6 and 8 had a lower yield than the other materials evaluated. Genotypes 9 and 6 had thicker husks, which, despite being a desirable characteristic during transport, is not desirable by the industry because it reduces the juice yield.

The significance of the $G \times Y$ interaction indicates that the years 2011 and 2012 provided conditions for most genotypes to express the maximum longitudinal diameter of the fruit. Of the 20 materials evaluated, 14 had the highest values in the 2012 harvest, with averages ranging from 72 to $76 \mathrm{~cm}$ for genotypes 49 and 4 , respectively. From this set, genotypes $4,9,13,22,39,46$, and 49 stands out, which maintained the averages obtained in the previous year's harvest, demonstrating stability for these characteristics.

Genotypes 9, 13, and 49 maintained the same means, regardless of the year of cultivation. Crasque et al. (2020) pointed out that the longitudinal and transversal diameter of the fruits, as well as the fruit mass, are parameters used to qualify the fruits and, consequently, to allocate them to the industry or fresh market. Therefore, sudden variations in the phenotypic characteristics between one year and another are not desirable, as both the industry and the fresh consumer have prioritized the maintenance of physical, sensory, visual, and performance characteristics. However, even with the adoption of appropriate cultural practices, these changes may occur, mainly reflecting edaphoclimatic variations or those inherent to the crop system.

Distinct results were observed for the transversal diameter of the fruit, for which most genotypes (40\%) were statistically higher in the 2010 harvest. The transversal diameter of the fruit from that year was $72 \mathrm{~cm}$, with variations between 67.58 and $76.89 \mathrm{~cm}$ for genotypes 33 and 40, respectively.

Within each year, it was found that genotypes 6, 8, 9, $13,19,22$, and 40 , in addition to the Aquiri cultivar, had greater transversal fruit diameter during the three harvests, demonstrating that there were few variations in this attribute, regardless of climatic conditions or intraspecific competition for water, light, and nutrients.

Continella et al. (2018) studied the influence of different rootstocks on the precocity productivity and quality of sweet orange fruits. They observed that it was among the possible factors (such as soil conditions) that potentially limit various

Table 3. Unfolding genotype $x$ year interactions to the longitudinal fruit diameter (LFD) and transversal fruit diameter (TFD) of 19 sweet orange genotypes, and Aquiri cultivar, evaluated for three consecutive years (2010, 2011 and 2012) in the Acre State, Brazil.

\begin{tabular}{|c|c|c|c|c|c|c|c|}
\hline & \multirow{2}{*}{ Genotype } & \multicolumn{3}{|c|}{ LFD (mm) } & \multicolumn{3}{|c|}{ TFD (mm) } \\
\hline & & 2010 & 2011 & 2012 & 2010 & 2011 & 2012 \\
\hline \multirow{14}{*}{$\begin{array}{c}\text { Unfolding } \\
\text { year } \times \text { genotype }\end{array}$} & 4 & $67.32 \mathrm{Cb}$ & $71.53 \mathrm{Ba}$ & $73.04 \mathrm{Aa}$ & $70.67 \mathrm{Bb}$ & $64.48 \mathrm{Cc}$ & $75.62 \mathrm{Aa}$ \\
\hline & 6 & $74.59 \mathrm{Aa}$ & $72.60 \mathrm{Bb}$ & $74.43 \mathrm{Aa}$ & $76.63 \mathrm{Aa}$ & $71.70 \mathrm{Ac}$ & $73.80 \mathrm{Ab}$ \\
\hline & 9 & $72.33 \mathrm{Aa}$ & $73.16 \mathrm{Aa}$ & $72.29 \mathrm{Aa}$ & $74.59 \mathrm{Aa}$ & $69.78 \mathrm{Ab}$ & $74.68 \mathrm{Aa}$ \\
\hline & 11 & $67.69 \mathrm{Cb}$ & $71.69 \mathrm{Ba}$ & $70.11 \mathrm{Ba}$ & $71.91 \mathrm{Bb}$ & $74.10 \mathrm{Aa}$ & $69.89 \mathrm{BC}$ \\
\hline & 22 & $73.97 \mathrm{Ab}$ & $75.90 \mathrm{Aa}$ & $75.76 \mathrm{Aa}$ & $75.85 \mathrm{Aa}$ & $71.65 \mathrm{Ab}$ & $75.42 \mathrm{Aa}$ \\
\hline & 24 & $67.12 \mathrm{Cc}$ & $71.89 \mathrm{Ba}$ & $70.62 \mathrm{Bb}$ & $68.46 \mathrm{Cc}$ & $75.03 \mathrm{Aa}$ & $72.40 \mathrm{Ab}$ \\
\hline & 25 & $67.16 \mathrm{Cb}$ & $45.35 \mathrm{Ec}$ & $72.79 \mathrm{Aa}$ & $69.08 \mathrm{Cc}$ & $70.48 \mathrm{Ab}$ & $73.60 \mathrm{Aa}$ \\
\hline & 33 & $62.52 \mathrm{Db}$ & $63.85 \mathrm{Da}$ & $60.66 \mathrm{Cc}$ & $67.58 \mathrm{Ca}$ & $66.37 \mathrm{Bb}$ & $64.47 \mathrm{Cc}$ \\
\hline & 38 & $70.20 \mathrm{BC}$ & $74.51 \mathrm{Aa}$ & $73.50 \mathrm{Ab}$ & $72.99 \mathrm{Ba}$ & $71.77 \mathrm{AC}$ & $73.64 \mathrm{Aa}$ \\
\hline & 39 & $67.13 \mathrm{Cb}$ & $70.22 \mathrm{Ba}$ & $69.53 \mathrm{Ba}$ & $71.78 \mathrm{Ba}$ & $70.39 \mathrm{Ab}$ & $70.18 \mathrm{Bb}$ \\
\hline & 47 & $69.65 \mathrm{Ba}$ & $67.76 \mathrm{Cb}$ & $70.18 \mathrm{Ba}$ & $71.32 \mathrm{Bb}$ & $66.48 \mathrm{Bc}$ & $72.36 \mathrm{Aa}$ \\
\hline & 49 & $71.17 \mathrm{Ba}$ & $70.99 \mathrm{Ba}$ & $70.97 \mathrm{Ba}$ & $71.41 \mathrm{Ba}$ & $68.47 \mathrm{Bb}$ & $69.00 \mathrm{Bb}$ \\
\hline & 52 & 71.37 Bb & $70.09 \mathrm{Bc}$ & $74.84 \mathrm{Aa}$ & $72.90 \mathrm{Bb}$ & $68.17 \mathrm{Bc}$ & $73.76 \mathrm{Aa}$ \\
\hline & Aquiri & $70.81 \mathrm{Bb}$ & $68.66 \mathrm{Cc}$ & $72.32 \mathrm{Aa}$ & $76.35 \mathrm{Aa}$ & $71.59 \mathrm{Ac}$ & $75.02 \mathrm{Ab}$ \\
\hline
\end{tabular}

Means followed by the same uppercase letter in the column and lowercase letter in the row do not differ by Scott-Knott test at $5 \%$ probability. 
vegetative aspects, including productivity and fruit quality. Therefore, it is necessary to understand the cultivation requirements for each genotype so that they can be cultivated at suitable sites and, later, fulfill their productive potential.

The Pearson correlation network, established between pairs, for the phenotypic variables of the studied genotypes, is shown in Figure 2. The red and green lines represent negative and positive correlations, respectively, and the thickness of the connecting lines demonstrates the intensity of the correlation between the variables.

It was possible to detect the presence of strong, weak, positive, and negative correlations among all variables. In the central and left peripheral regions of the figure are variables with strong correlations. The yield per plant was positively correlated with the number of fruits per plant and yield, and moderately correlated with the ratio.

On the other hand, the number of fruits per plant and production per plant was negatively correlated with titratable acidity and juice yield. The rootstock used characteristically extracts more water from the soil, which induces the formation of larger fruits; and therefore, the levels of soluble solids and titratable acidity tend to decrease, which implies a change in fruit quality.

In the right peripheral region of Figure 2, the average fruit mass, longitudinal fruit diameter, and transversal fruit diameter were grouped, and were positively correlated with each other. This group of variables has weak negative correlations with juice yield, titratable acidity, and technological index. It is also possible to visualize a weak positive correlation between this group and the soluble solid content.

For the groupings of the evaluated genotypes (Figure 3), it was observed that by the Ward method and Mahalanobis

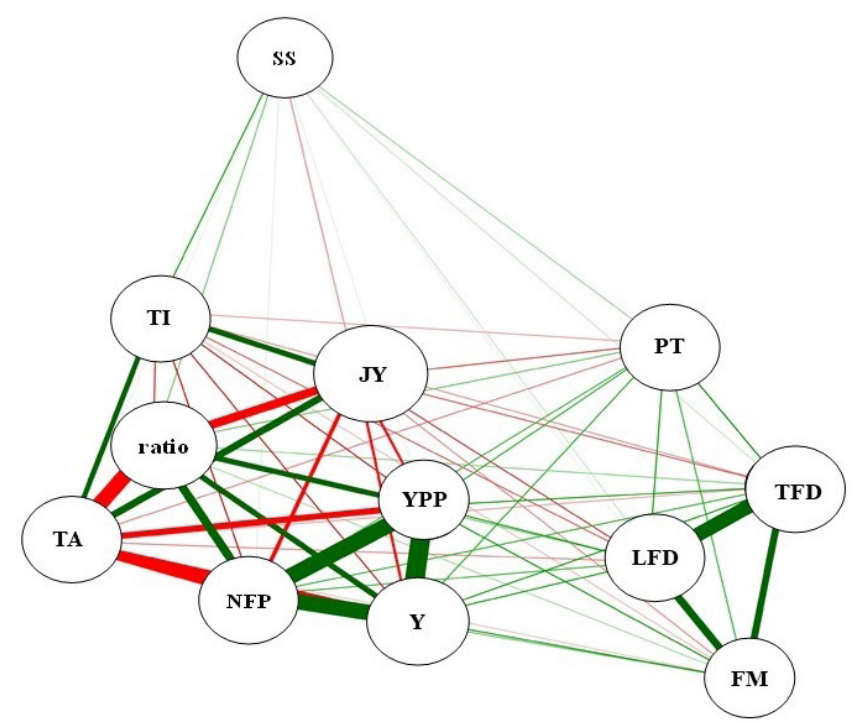

Figure 2. Correlation network for the variables number of fruits per plant (NFP), average fruit mass (FM), yield per plant (YPP), yield $(\mathrm{Y})$, longitudinal fruit diameter (LFD) and transversal fruit diameter (TFD), juice yield (JY), peel thickness (PT), soluble solids (SS), titratable acidity (TA), ratio (SS/TA), and technological index (TI) of fruits of 20 sweet orange genotypes evaluated in the years 2010, 2011, and 2012 in the Acre State, Brazil. The red and green lines represent negative and positive correlations, respectively, and the line width is proportional to the strength of the correlation (Epskamp et al., 2012).

distance, four groups were formed. It is estimated that among the characteristics of each genotype, similarities are evident, corroborating the distinctions of each of them.

Among the variables evaluated, the genotypes with the best response $(6,8,9,52$, and Aquiri cultivar) were found in

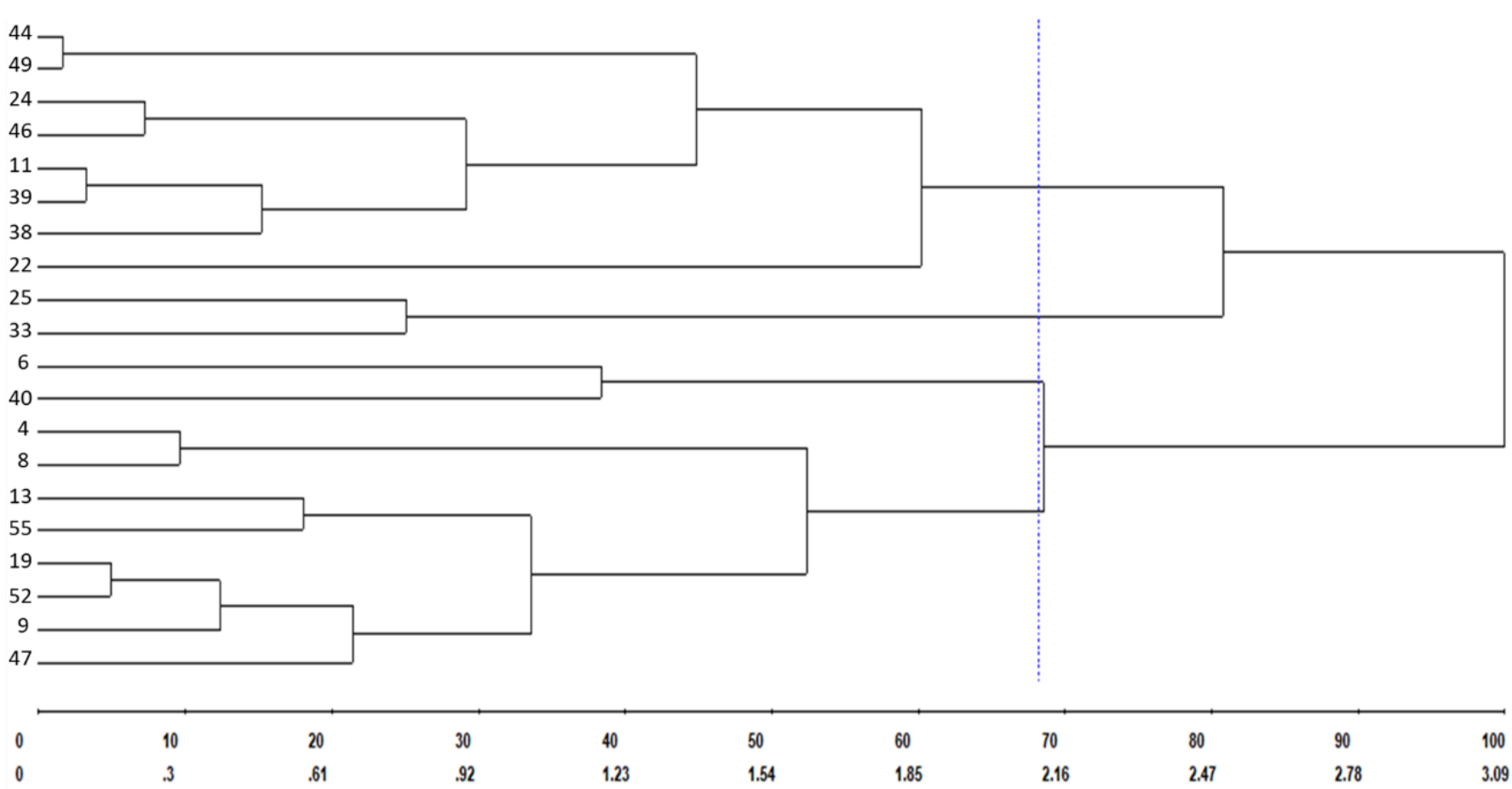

Figure 3. Dendrogram of 20 orange sweet genotypes by the Ward method from the Mahalanobis distance based in 12 agronomical characters. Genotype 55 refers to Aquiri cultivar. 
Table 4. Demonstration of the groups of genotypes formed from Ward method and the Mahalanobis distance.

\begin{tabular}{cc}
\hline Groups & Genotypes \\
\hline I & $11,22,24,38,39,44,46$ e 49 \\
II & 25 e 33 \\
III & 6 e 40 \\
IV & $4,8,9,13,19,47,52$ and Aquiri cultivar \\
\hline
\end{tabular}

groups III and IV (Table 4), and, because of this, it was possible to verify that these groups had promising potential.

\section{Conclusions}

Genotypes 6, 8, 9, and 52 have productive indicators similar to the local Aquiri cultivar, and meet the minimum fruit quality criteria, with a yield above the Brazilian national average and, therefore, show promise for the cultivation of sweet orange cultivars in the Acre State.

\section{Compliance with Ethical Standards}

Author contributions: Conceptualization: RSB, RAA, RCAN; project administration: RCAN; formal analysis: RSB, RAA, RCAN; Methodology: RSB, RAA; Supervision: RCAN; Validation: RSB, RAA, RCAN; Visualization: RSB, RAA, RCAN; Writing - original draft: RSB, RAA; Writing - review \& editing: RSB, RAA, RCAN.

Conflict of interest: The authors declare no conflict of interest.

Funding: Embrapa Acre.

\section{Literature Cited}

Alvares, C.A.; Stape, J.L.; Sentelhas, P.C.; Gonçalves, J.L. de M.; Sparovek, G. Köppen's climate classification map for Brazil. Meteorologische Zeitschrift, v.2, n.6, p.11-728, 2013. https://doi. org/10.1127/0941-2948/2013/0507.

Andrade Neto, R. de C.; Negreiros, J.R. da S.; Araújo Neto, S.E. de; Cavalcante, M. de J.B.; Alecio, M.R.; Santos, R.S. Gargalos tecnológicos da fruticultura no Acre. 1.ed. Rio Branco: Embrapa Acre, 2011. p.14-18.

AOAC International. Official methods of analysis of the AOAC International. 19.ed. Arlington: AOAC International, 2012.

Beber, P.M.; Alvares, V. de S.; Kusdra, J.F. Qualidade industrial e maturação de frutos de laranjeiras-doce em Rio Branco, Acre. Citrus Research \& Technology, v.39, e-1030, 2018. https://doi. org/10.4322/crt.10317.

Bhering, L. Rbio: A tool for biometric and statistical analysis using the $\mathrm{R}$ platform. Crop Breeding and Applied Biotechnology, v.17, n.2, p.187190, 2017. https://doi.org/10.1590/1984-70332017v17n2s29.

Brasil. Ministério da Agricultura, Pecuária e Abastecimento. Instrução Normativa no 37, de 10 de outubro de 2018. Estabelece parâmetros analíticos de suco e de polpa de frutas e a listagem das frutas e demais quesitos complementares aos padrões de identidade e qualidade já fixados pelo Ministro da Agricultura, Pecuária e Abastecimento através da IN MAPA no 49, de 26 de setembro de 2018. Diário Oficial da União, v.155, n.194, seção 1, p.23-33, 2018.
Carvalho, H.W.L. de; Teodoro, A.V.; Barros, I. de; Carvalho, L.M. de; Soares Filho, W. dos S.; Girardi, E.A.; Passos, O.S.; Pinto-Zevallos, D.P. Rootstock-related improved performance of 'Pera' sweet orange under rainfed conditions of Northeast Brazil. Scientia Horticulturae, v.263, e108148, 2020. https://doi.org/10.1016/j. scienta.2019.109148.

Carvalho, L.M. de; Carvalho, H.W.L. de; Barros, I. de; Martins, C.R.; Soares Filho, W. dos S.; Girardi, E.A.; Passos, O.S. Novas combinações de enxerto-porta-enxerto para diversificação de pomares de laranja doce em solos tropicais de consolidação. Scientia Horticulturae, v.243, p.169-176, 2019. https://doi. org/10.1016/j.scienta.2018.07.032.

Coelho, B.E.S.; Duarte, V.M.; Silva, L.F.M. da.; Sousa, K. dos S.M. de.; Figueiredo Neto, A. Atributos físico-químicos de frutos de laranja 'Pêra' produzidos sob sistemas de cultivo orgânico e convencional. Revista Brasileira de Meio Ambiente, v.5, n.1, p.128-137, 2019. https://www.revistabrasileirademeioambiente. com/index.php/RVBMA/article/view/180/162. 09 Sep. 2020.

Continella, A.; Pannitteria, C.; Malfaa, S. La; Leguab, P.; Distefanoa, G.; Nicolosia, E.; Gentilea, A. Influence of different rootstocks on yield precocity and fruit quality of 'Tarocco Scirè' pigmented sweet orange. Scientia Horticulturae, v.230, p.62-67, 2018. https://doi.org/10.1016/j.scienta.2017.11.006.

Costa, L.F. dos S.; Ferreira, E. de M.; Junqueira, P.H.; Lobo, L.M.; Muniz, C.O.; Isepon, J. dos S. Características fisicoquímicas e produtividade da laranja 'Pera' em função da aplicação de aminoácidos em cobertura. Revista Trópica: Ciências Agrárias e Biológicas, v.10, n.1, p.53-62, 2018. http://www. periodicoseletronicos.ufma.br/index.php/ ccaatropica/article/ view/2459/6225. 09 Sep. 2020.

Couto, C.A. do; Souza, E.R.B. de; Morgado, C.M.A.; Ogata, T.; Cunha Junior, LC. Cultivares de Citrus sinensis: alternativas para diversificação dos pomares brasileiros. Revista Brasileira de Fruticultura, v.40, n.5, e097, 2018. https://doi.org/10.1590/010029452018097.

Crasque, J.; Cerri Neto, B.; Souza, G.A.R. de; Costa, R.J.; Arantes, L. de O.; Arantes, S.D.; Alvez, F. de. Características físico-químicas de frutos de laranja em diferentes porta-enxertos. International Journal of Development Research, v.10, n.8, p.39534-39539, 2020. https://doi.org/10.37118/ijdr.19640.08.2020.

Cruz, C. D. GENES: a software package for analysis in experimental statistics and quantitative genetics. Acta Scientiarum. Agronomy, v.35, n.3, p.271-276, 2013. https://doi.org/10.4025/actasciagron. v35i3.21251.

Epskamp, S.; Cramer, A. O. J.; Waldorp, L. J.; Schmittmann, V. D.; Borsboom D. qgraph: network visualizations of relationships in psychometric data. Journal of Statistical Software, v.48, n.4, p118, 2012. https://doi.org/10.18637/jss.v048.i04.

Fadel, A. L.; Stuchi, E. S.; Couto, H. T. Z.; Ramos, Y. C.; Mourão Filho, F. de A. A. Trifoliate hybrids as alternative rootstocks for 'Valencia' sweet orange under rainfed conditions. Scientia Horticulturae, v.235, p.397-406, 2018. https://doi.org/10.1016/j. scienta.2018.01.051.

Food and Agriculture Organization of the United Nations - FAO. Faostat. Food and agriculture data - 2019. http://www.fao.org/ faostat/en/\#data/QC/visualize. 19 Sep. 2020. 
Gonçalves, G.S.; Carvalho, J.E.B.; Garcia, M.V.B.; Gama, L.A.; Azevedo, C.L.L.L.; Silva, J.F. periods of weed interference on orange tree crops. Planta Daninha, v.36, e.018179810, 2018. https://doi. org/10.1590/S0100-83582018360100080.

Gondim, T.M. de S.; Rtzinger, R.; Cunha Sobrinho, A. P. da. Seleção e caracterização de laranjeiras-doces (Citrus sinensis (L.) Osbeck) no Estado do Acre. Revista Brasileira de Fruticultura, v.23, n.2, p.451454, 2001. https://doi.org/10.1590/\$0100-29452001000200052.

Instituto Nacional de Meteorologia - INMET. Estação meteorológica de observação de superfície automática. http://www.inmet.gov. br. 20 Dec. 2019.

Instituto Brasileiro de Geografia e Estatística - IBGE. Levantamento Sistemático da Produção Agrícola - Ano 2019. https://sidra.ibge. gov.br/Tabela/1618\#resultado. 19 Sep. 2020.

Kirinus, M.B.M.; Oliveira, R.P. de; Silva, P. S.; Barreto, C.F.; Malgarim, M.B.; Soares Filho, W. dos S. Agronomic performance of 'Valência' orange combined with 13 rootstocks in the state of Rio Grande do Sul, Brazil. Pesquisa Agropecuária Brasileira, Brasília, v.54, e00461, 2019. https://doi.org/10.1590/s1678-3921.pab2019.v54.00461.

Ledo, A.S.; Ledo, F.J.S.; Ritzinger, R.; Cunha Sobrinho, A. P. Portaenxertos para laranjeiras-doces (Citrus sinensis (L.) Osb.), em Rio Branco, Acre. Pesquisa Agropecuária Brasileira, v.34, n.7, p.1211-1216, 1999. https://doi.org/10.1590/S0100204X1999000700013

Ledo, A. S.; Ledo, F. J. S.; Ritzinger, R.; Pimentel, F. A.; Azevedo, F. F. Recomendação da laranja Aquiri e técnicas para o plantio no estado do Acre. Rio Branco: Embrapa Acre-1997. 4p. (Embrapa Acre. Comunicado técnico, 73).
Legua, P.; Forner, J.B.; Hernandeza, F.; Forner Ginerb, M.A. Physicochemical properties of orange juice from ten rootstocks using multivariate analysis. Scientia Horticulturae, v.160, p.268273, 2013. https://doi.org/10.1016/j.scienta.2013.06.010.

Negreiros, J. R. D. S.; Andrade Neto, R. D. C.; Miqueloni, D. P.; Lessa, L. S. Estimativa de repetibilidade para caracteres de qualidade de frutos de laranjeira-doce. Pesquisa Agropecuária Brasileira, v.49, n.1, p.40-48, 2014. https://doi.org/10.1590/S0100$204 \times 2014000100006$.

Panta, A.M. dos P.; Santos Sobrinho, V.R.A. Agronegócio da citricultura sergipana entre 2010 a 2017. Citrus Research \& Technology, v.40, e.1050, 2019. https://doi.org/10.4322/crt.17419.

Santos, H. G. dos.; Jacomine, P. K. T.; Anjos, L. H. C. dos.; Oliveira, V. Á de; Lumbreras, J. F.; Coelho, M. R; Almeida, J. A. de.; Araújo Filho, J. C. de.; Oliveira, J. B. de; Cunha, T. J. F. Sistema brasileiro de classificação de solos. 5.ed. Brasília: Embrapa, 2018. 356p.

Silva, A.C.R.; Almeida, G.M.de; Lobato, W.T. dos S.; Almeida, F.S. de. S.; Souza, A.A.S. de; Vidal, D.J.F.; Lima, E do S.F.; Pereira, W.C. Estudo da produção de laranja: Detecção de características regionais com modelos de shift-share e derivada na região Norte. Agroecossistemas, v.9, n.2, p.164-183, 2017. https://doi. org/10.18542/ragros.v9i2.5027.

Teodoro, A.V.; Carvalho, H.W.L. de; Barros, I. de; Carvalho, L.M. de; Martins, C.R.; Soares Filho, W. dos S.; Girardi, E.A.; Passos, O.S. Performance of 'Jaffa' sweet orange on different rootstocks for orchards in the Brazilian Northeast. Pesquisa Agropecuária Brasileira, v.55, e01665, 2020. https://doi.org/10.1590/S16783921.pab2020.v55.01665. 